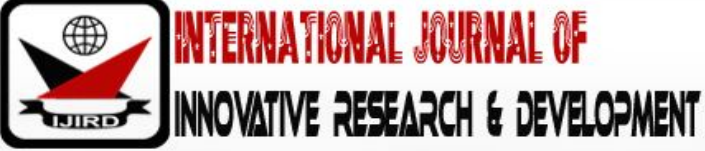

ISSN 2278 - 0211 (Online)

\section{The Attorney-in-School Program as a Tool of Social Communication in Increasing Society's Law Awareness Especially School Teenagers}

\author{
Muh. Ibnu Fajar Rahim \\ Student, Department of Doctoral Program Law, Universities Muslim
}

\begin{abstract}
:
The Attorney-in-School program is a social communication tool in realizing the task execution of the Judiciary of Republic of Indonesia in the field of discipline and public tranquility to administer the activity of society's law awareness improvement. The Attorney-in-School program, as a part of Judiciary law, is in charge of connecting between the law rules and the society, especially the school teenagers. The Attorney-in-School program focuses on the improvement of the society's law awareness, especially the school teenagers, in order to avoid them to against the law. The effectiveness of the Attorney-in-School program is very determined by an attorney's intellectual quality, as a user who will lead the Attorney-in-School program as a social communication tool for the society, especially for the school teenagers.
\end{abstract}

Keywords: Attorney-in-School, social communication tool, law awareness

\section{Background of Problems}

The manifesto of Article 30 Section (3) letter-aof Constitution of Republic of Indonesia No. 16 Year 2004 About Judiciary of Republic Indonesia, demands the Judiciary of Republic of Indonesia (hereafter is called Judiciary) to administer an activity of society's law awareness improvement as a duty realization of the division of discipline and public tranquility. The Attorney General's responsive action to such attribution authority is to publish the Decision of Attorney General of Republic Indonesia No. 184/ A/JA/ 11/2015 on November 18, 2015, About the Formation of Attorney-in-School of the Judiciary of Republic of Indonesia. Such normative implication of Attorney General's Decision, causes the Attorney-inSchool (hereafter is called JMS) program to be a part of Judiciary Law. The JMS program is a responsive form to the Nawacita (the nine main agenda or vision-mission) belongs to the President of Republic of Indonesia, Joko Widodo, particularly the eighth cita (agenda) which is "To execute the Revolution of the Character of Nation." This JMS program is indeed specialized to stray teenagers or youngsters as the target, due to their vulnerabilities of deviated behaviors and violating the law (onrechtmatigheid).

Judiciary, as a government agency administering authority in the field of law establishment, is morally responsible to advance young generation of students to always understand and comprehend about law and its problems. Judiciary considers that students are the main door of a young generation which has the nation-and-country's goal and direction in the future. That is to say, the future of nation and country is determined by the school teenagers or student's qualities, abilities, and readiness,

The enforcement of activity of law-abiding society (hereafter is called binmatkum), especially in this JMS program, points to increase the law awareness of the young generation so they have an understanding, awareness, and doing their rights, obligations, and responsibilities, as the next generation of the nation development's goals. The understanding about law awareness in young generation is expectedly able to reduce the crime rate, especially on the child case. According to the JMS's slogan: "Know the Law, Avoid the Punishment;" means that by understanding the law, then will be able to stay away from doing anything that is against the law, which can cause punishment or sanctions.

The law reality, presenting the crime rate done by the doer especially children, keep increasing each year. In responding such law reality, it requires a preventive act to overcome it. The JMS program is one of legal solutions in facing such law reality. JMS program, as a part of Judiciary Law, is the Judiciary's communication tool which has the role to distribute law science that aims to increase the society's law awareness, especially the young generation, as a preventive effort for the cause of law violation or the acts against law, particularly in the circle of students or young generations. Based on such matters, thus this writing aims to study the essence of the JMS program as a social communication tool in decreasing crime done by school students.

\section{Discussion}

The law awareness is cognition or the values included inside humans about the existed law or about the law that expectedly exists. The law awareness emphasizes about the society values about what functions that are right to be 
performed by the law in the society ${ }^{1}$.The society's understanding and obedience or adherence to the law norms and the valid legislation regulation, are the realization of the society's law awareness as a value living in the society. The coaching of the society's law awareness through law counselling intends to increase the society's understanding about law including the regulated rights and obligations, and to create the law-abiding society and obey the law based on the high law awareness. The mechanism and ways in communicating the messages of law counselling have to be matched by the compound needs and stratification of Indonesian society. Based on such conception, according to Soerjono Soekanto, there are four indicators about the formation process of law awareness, namely:

- Law science:is when a person recognizes that such behaviors have been regulated by law. Such law science is either the written or unwritten law. Such behaviour involves either the law-forbidden or the law-allowed behaviour;

- Law understanding: is when a society member has the knowledge and understanding about certain rules;

- Law attitude: is when a person tends to have a certain evaluation to law;and also

- Law behaviour pattern: is when a person, or the member(s) of society, obeys the applicable regulation. ${ }^{2}$

From the four points above, the formed of the law behaviour pattern is the highest degree of law awarees. Law behaviour pattern is the last destination in the theory of law awareness. Through this law behaviour pattern, it can be rated where a law regulation in a society is applied effectively or not. The high degree of law awareness makes the society obey the certain law provisions. On the contrary, the low degree of law awareness causes tyranny and increases criminality caused by low obedience to the law.

In accordance with the validity of a legislation regulation, then law awareness basically is a connector variable between the compulsion within the regulation and the society's behaviours ruled by that law. Therefore, whether the legislation is effective or not in managing society's behaviours, it will depend on that society's law awareness level.

As an effort to create such law behavior pattern, then one of criminal countermeasure perspectives can be used is the effort of preventive or precaution. The precaution effort is before such criminal act happens. A preventive strategy must be made and held by leading it to the things which can cause it, including the criminal act doer. To prevent and avoid the breaking-the-law occurrence, it needs to increase the law awareness in society.

Realizing such matters, President of Republic of Indonesia, Ir. Joko Widodo, tries to realize the enhancement of the society's law awareness through the Nawacita program, especially the eighth cita, which is "To Execute the Revolution of the Character of Nation." Judiciary of Republic of Indonesia, as a government agency, responds the president's Nawacita by publishing the Decision of Attorney General of Republic of Indonesia No. 184/ A/ JA/ 11/ 2015 in November 18, 2015, About the Formation of Attorney-in-School (JMS) Team of Judiciary of Republic of Indonesia. The normative implication of the Decision of Attorney General causes the JMS program as a part of the Judiciary Law. The Attorney General, H. M. Prasetyo, states that JMS Program is meant to give law education for the society since early age. 3 This JMS Program is specialized to stray youngsters and teenagers as the target due to their vulnerabilities of deviated behaviors and violating the law (onrechtmatigheid).

Therefore, through a preventive step or lawlessness prevention in the community of children (students) in the form of a coaching activity of law-abiding society (Binmatkum) which is the Program of Attorney-in-School (JMS), can minimize the crime rate in children. Recorded, from January 2018 till June 2018, Judiciary had held about 480 activities of JMS Program in schools or even universities.

JMS Program is a law instrument which connects between legislation regulation and the society. JMS Program functions to communicate the meaning of legislation regulation to the law subject: human, society, especially the school teenagers. JMS Program is a social communication tool which brings a vision to execute the nation character revolution in manifesting the President Jowo Widodo's nawa cita which is the eighth cita, "To Execute the Revolution of Character of Nation." To carry out the mission to increase the society's law awareness, especially the school teenagers, in order to obey the law regulation, and to prevent the society to do acts which against the law.JMS Program as a social communication tool is a precaution effort to the possibility of executed crime before the crime ever happens. JMS program as a social communication tool aims to create a certain condition in order to prevent any crimes, or crime prevention is an effort involving all actions which have special destination to minimize the crime scope through the efforts of influencing the people which can potentially become offenders, and to the public society.

JSM Program tries to communicate the law regulations to society, especially school teenagers, to create a law science in order to give understanding to the society, especially the school teenagers, about which behaviors should be done, and which behaviors are forbidden by the law regulation, and also the consequences of disobeying the law regulations.The establishment of knowledge and understanding through JMS Program as a social communication tool is expectedly able to create a law behavior to behave according to the law regulation by the society, especially the school teenagers. The synergy of law science, law understanding, then such law behavior, through JMS Program as a social communication tool, undoubtedly can form the law behavior pattern as a manifestation of the formation of society's law awareness, especially school teenagers.

Considering the JMS Program was just held in 2016, then the role played by JMS Program is very determined by the Judiciary's human resource who will play the role of JMS Program. The intellectual quality of an Attorney is very decisive whether the law communication between the law regulation and the society can run effectively. Because an 
Attorney is the main character who will play the JMS Program as the social communication tool in order to give the understanding and comprehend about law regulation to the society, especially the school teenagers.

The JMS Program is an effort to increase the Judiciary's part in the field of discipline and public tranquility through the activity of increasing the society's law awareness, especially the students or school teenagers. JMS Program is one form of law counselling and law information for the society, especially for the students and school teenagers. The law counseling and law information aim to reach the high level of law awareness in the society, so every society member realizes their rights and obligations as a citizen in order to uphold the law and to reach the discipline and public tranquility. In order to increase the society's law awareness, then Judiciary performs the activity of law information and law counseling through the program of law-abiding society training (BinMatKum). The implementation of Binmatkum Program, not only as an effort to increase the society's law awareness, but also to give law information to the society as fast as possible, as the Judiciary's imaging tool and as the preventive tool in upholding the law, done by Judiciary.

\section{Suggestion and Conclusion}

The JMS Program is a law embodiment as a social communication tool. The role played by JMS as an embodiment of social communication tool, is the increasing of society's law awareness, especially school teenagers. JMS Program as a part of Judiciary Law, focused on the increasing of society's law awareness, especially students or school teenagers, by giving law knowledge and law understanding to create law behavior along with the law behavior pattern as the embodiment of the increasing of society's law awareness which prevents the society, especially students or school teenagers, to not act against the law. JMS Program is very determined by the intellectual quality of an Attorney in playing the JMS Program's role which will connect the law regulation with the society, especially the students or the school teenagers.

Since the role played by JMS Program is very determined by the quality of Judiciary's human resource which will play the JMS Program's role, then it is expected that the Attorneys also increase their theoretical skills, practical skills, and social communication skills.

\section{References}

i. Keputusan Jaksa Agung Republik Indonesia Nomor : 184/ A/JA/11/2015 tanggal 18 Nopember 2015 Tentang Pembentukan Tim Jaksa Masuk Sekolah (JMS) Kejaksaan Republik Indonesia.

ii. $\quad$ R. Otje Salman. 1989. Beberapa Aspek Sosiologi Hukum. Alumni. Bandung.

iii. Soerjono Soekanto. 2005. Pendekatan Sosiologi Terhadap Hukum. Bina Aksara. Jakarta.

iv. Undang-Undang Republik Indonesia Nomor 16 Tahun 2004 Tentang Kejaksaan Republik Indonesia.

v. https:// news.detik.com/ berita-jawa-timur/ d-3443765/ jaksa-agung-launching-program-jaksa-masuk-sekolah, diakses tanggal 01 Oktober 2018. 